\title{
몰디브 원조공여국 회의 결과
}

최근 몰디브에서 원조공여국 회의가 개최된 바, $\mathbb{I I}$. 주요 회의 내용 주요 내용은 다음과 같음

\section{I. 동 회의 참석자}

ㅁ정부대표 참석 국가:우리나라를 비롯, 호주, 캐나 다, $\mathrm{EU}$, 핀랜드, 이태리 미국, 오만 등 8개국

묵제기구:아시아개발은행, 세계은행, UNDP, $\mathrm{UNICEF}, \mathrm{UNEP}$, 일본국제협력은행(JBIC), 이슬 람개발은행, 아랍경제개발을 위한 쿠웨이트 펀드 (DFAED), 사우디개발펀드(SFD) 등 9 개 기관

ㅁ몰디브 정부:Mohamed 재정 및 금융부장관, Hamdun Hameed 기획 및 국가개발부장관 등 8명

NGO:몰디브, 필리핀, 대만 등의 $\mathrm{NGO} 11$ 개 단체 참석

1. 몰디브 정부 지진해일피해 및 복구재원 소요 현황 설명

1) 몰디브 지진 · 해일 피해현황

ㅁ몰디브는 금번 지진 · 해일 피해금액은 470.1 백 만불로 몰디브 $\mathrm{GDP}$ 의 $62 \%$ 에 해당하는 피해를 입었음.

-’04년 현재 인구 29만 명 중 83명 사망, 26 명 실 종, 약 21,500 명의 이재민이 발생하였고 몰디브 전체인구의 약 $33 \%$ 인 10 만 여명이 직간접적으 로 영향을 받음.

-전체 1192 개 섬 중 199 개 섬에 사람이 거주하고 있으나 그 중 104 개 섬이 피해를 입었으며 전기 두절 26 개 섬, 통신시설 피해 70 개 섬, 학교 - 병 원 등 공공시설 피해 50 개 섬 파손, 어선 50척, 리조트 시설이 있는 87 개 섬 중 21 개 섬이 폐쇄 중임. 
-환경적으로는 해안침식, 지하수 오염, 산호초 파 손, 육지의 염분화 등의 피해를 입음.

\section{2) 몰디브의 복구 · 재건}

ㅁㅈ지진해일 피해 발생후 몰디브 정부는 1 월 26 일 이 후부터 본격적인 재건복구 프로그램 준비를 시작 하였으며 동 재건복구사업을 총괄하기 위해 국가 재난관리센터(National Disaster Management Center)를 설치하고 복구작업을 본격화 함.

-몰디브 정부는' 05 년 3 월 현재 상수도, 전기, 통 신, 임시거주, 학교수업 개시 등 응급복구 상태 는 성공적으로 완료된 상태이나 완전히 재건 · 복구하는데는 주택건설, 통신시설 개선, 해양방 조시설 등 향후 $5 \sim 8$ 년이 소요될 것으로 예상됨.

ㅁ몰디브 정부는 구호 - 재건 · 복구 기금 운영의 투 명성 및 책임성 확보를 위해 감사원장을 위원장으 로 하는 감시위원회(Board of Trustees)를 설치하 여 운영중임

ㅁ추정 소요비용

-몰디브 정부는 관광산업 재건에 100 백만불, 주택건설분야에 74 백만불, 통신시설 복구 등 행정분야에 50 백만불, 상수도 및 염분화된 토 지 담수화 사업에 45.6 백만불 등 총 406.3 백 만불의 비용이 소요되며 총 소요비용 중 국제 사회의 지원이 필요한 비용은 304.2 백만불이 라고 설명함.

ㅁ몰디브 정부는 그간 몰디브를 위해 구호금 및 현물 지원을 해준 한국, 일본, $\mathrm{EU}$, 국제기구 및 $\mathrm{NGO}$ 등의 적극적인 지원에 사의를 표명함.

\section{3) 재건 · 복구과정에서 문제점}

ㅁ 20개 산호군으로 구성된 섬지역에 복구 · 재건 지 원을 위한 접근 곤란

ㅁ섬들 지역으로 수송비용의 과다

ㅁ 복구 · 재건 자원 부족 등

\section{2. $U N$ 지원현황 $U N D P$ 의 몰디브 $U N$ 상주 조정관} Partice Coeur-Bizot 발표)

ㅁ긴급수요 우선순위:국민들의 삶 재건(Livelihood), 주택, 수송 및 인프라, 재해위험관리, 수자 원 및 담수화 작업 및 공공행정 분야 순으로 재 건 · 복구 과정에서 특별한 조정이 필요함.

ㅁ UN은 몰디브 재건 · 복구를 위해 66.5 백만불을 가용할 계획이며 3 월 17 일 현재 각국 정부, 정부간 기구 및 9개 UN기관(OCHA, UNICEF, UNDP, $\mathrm{WHO}, \mathrm{FAO}, \mathrm{UNEP}$ 등)으로부터 63.4백만불을 확보하였으며 ' 05 년 12 월까지 추가기금을 조성할 계획임.

ㅁ UN지원 우선분야

-이재민 구호 및 지원

-몰디브 경제회복 및 수산업, 농업 및 중소기업 복구

-교육, 보건, 수자원 등에 대한 사회서비스의 복구

-수자원 및 산호초 보존 등 환경보호

매개건 · 복구시 유의사항

-현재의 구호단계로부터의 장기개발계획으로 이 행단계에서 연계 및 철저한 준비 필요

-수자원, 담수화, 환경 등 복구단계시 통합적인 
개발계획 필요

- 미래를 대비한 탄력 있는 피난대책 및 인프라 설치

-재건이 필요한 적재적소에 필요한 재원을 투입 하여 수산업, 농업 등의 재건

-재난대비태세 및 조기경보체계 구축

-재건복구과정에서의 환경보전에 대한 충분한 고려 등

\section{3. 국제기구 對몰디브 지원}

마시아개발은행(ADB):ADB는 쓰나미 피해복구를 위해 설립한 아시아쓰나미기금(ATF) 중 몰디브의 인프라, 주택재건, 빈민층을 위해 무상 20 백만불 및 Loan으로 1.8 백만불을 지원할 계획임.

ㅁ이슬람개발은행(IDB):IDB는 쓰나미 피해국가를 위해 500 백만불을 지원할 계획인 바, 그 중 55.5 백만불을 몰디브에 지원할 예정이며 세부적으로 긴급원조를 위해 50 만불을 전달하였으며 무이자 Loan으로 20 백만불, 통상 금융이자로 15 백만불 및 수입무역(Import trade) 자금으로 20백만불을 각각 지원예정임.

-주요 지원희망 분야는 수송, 공공시설, 교육, 보 건분야이며 구체적인 사업분야는 4 월 초에 몰디 브 정부와 협의할 예정임.

ㅁ세계은행(WB): WB는 몰디브에 총 40 백만불을 지원할 예정이며 그중 $40 \%$ 를 무상으로 지원할 계 획이며 금번 회의 종료후 몰디브 정부와 서명할 예정임.

기타:사우디 펀드(20백만불) 및 쿠웨이트 펀드대
표(30백만불)는 몰디브 지원을 약속함.

\section{4. 각국의 對몰디브 지원}

ㅁㅇㄱ국: 우리 정부는 對몰디브 지원계획으로 금년부 터 3 년간 2 백만불 지원 약속, 즉 긴급구호자금 0.14 백만불, 긴구호물자 0.2 백만불 및 도서간 무 선통신설비 복구분야(2.262백만불 소요)에 1.65 백 만불을 지원하되 추가 소요예산 지원여부는 추후 몰디브 정부와 협의할 예정임.

-아울러 우리 정부는 $\mathrm{KOICA}$ 를 통해 91년부터 14년간의 무상원조실적(0.6363만불) 및 금년도 9 만불 규모의 무상원조를 계획중임.

미국:미국대표는 금번 지진해일 피해를 입은 서 남아시아국에 지원할 10 억불 규모의 예산을 의회 에 제출하여 의회의 승인을 기다리고 있다며 의 회가 승인하는데로 몰디브 지원계획을 발표할 예 정임.

ㅁ EU:EU는 2.7백만 유로를 긴급 지원하였고 14 백 만불을 상수도, 어선 및 환경재건을 위해 구호금을 사용할 것을 발표하였고 대몰디브 참시 수입쿼터 및 무역관련지원을 하기로 하였으며 유럽투자은 행(EIB)을 통해 향후 중소기업, 관광, 어업 등에 50 백만불의 soft loan을 추가 지원할 예정임.

ㅁ일본: 일본국제협력은행(JBIC)은 몰디브에 20 백 만불을 지원약속하였고 3월 말경 JICA를 통해 공 공건물, 어업분야 등의 기술자를 몰디브에 파견할 예정임. 특히 일본 정부는 몰디브 정부로부터 soft loan 지원요청이 있었으며 현재 일본 정부는 지원 여부를 심의중임. 


\section{III. 관찰 및 평가}

ㅁ몰디브 정부는 금번 원조공여국 회의를 통해 재 건 · 복구를 위해 필요한 소요비용의 약 $80 \%$ 를 국 제사회로부터 지원약속을 받음으로써 향후 몰디 브 재건을 위한 각종 사업 이행은 탄력을 받을 것 으로 예상됨.

- 동 사실은 금번 지진해일 피해 이후 재건복구를 위한 몰디브 정부의 노력이 국제사회로부터 인 정을 받은 것으로 평가되며 특히 원조금액의 집 행과정에서 감시를 철저히 하기 위해 구성된 감 시위원회에 국제기구 인사를 임명하는 등 투명 한 행정확보를 위한 노력과 지진해일 피해 이후 약 80 일이 경과한 현재 재건복구 프로그램 및 사업을 분야별로 철저히 준비한 것으로 평가됨.
ㅁ우리 정부가 몰디브에 지원예정인 도서간 무선통 신사업 관련, 몰디브 대표단은(외교부 외자국 부국 장 Ms. Aminath Didi) 우리 대표단을 만나 동 사 업 소요금액과 우리 지원금액 간의 차액 61 만불에 대해서는 금번 회의 후 양국 정부간 추가 협의하기 를 희망하여 왔음.

ㅁ참고로 몰디브 대표단이 일본의 JBIC에 $\mathrm{EDCF}$ 자금지원을 요청하였음에 비추어 우리 정부에 대해 $\mathrm{EDCF}$ 자금 지원 요청 가능성도 있는 것으 로 판단됨.

[자료:주몰디브 대사관] 